\title{
Váltólapkák tervezése és gyártása
}

\author{
Szerző: Turi Péter
}

\section{Tartalmi kivonat:}

A korszerũ, gazdaságos forgácsolás elképzelhetetlen megfelelő minőségũ szerszám nélkül. Mind a szerszám anyagának, mind geometriájának meg kell felelnie a követelményeknek.

A dolgozat az esztergaszerszámok példáján keresztül a ma már általánosan használt váltólapkák homlokfelületének tervezési és gyártási problémáival foglalkozik. A homlokszög nagyságával és a homlokfelület kialakitásával szabályozható a forgácsolóerõ nagysága, a lapka forgácstörő képessége, a forgács feltapadási hajlama, a lapka hőterhelése, stb. A homlokfazetta léte, illetve mérete attól függ, hogy a lapkát nagyoló, elősimító, vagy simító mũveletek során kívánják-e felhasználni.

A lapka gyártása porkohászati módszerrel történik: A sajtolószerszám negativja testesíti meg a homlokfelület geometriáját. A sajtolószerszám anyaga keményfém, gyártása szikrácsolással tơrténik. Az alapfeladat tehát végsősoron a szikrácsoló elektróda elkészitése. Egyszerübb geometriájú homlokfelület esetén az elektróda marásához szükséges NC program könnyedén elkészíthető, egy bizonyos bonyolultsági fok felett viszont már csak CAD/CAM rendszer használatával oldható meg a feladat. A technológia sajátossága továbbá, hogy a szerszám csak akkor múködhet tökéletesen, ha az elektróda felületén a megmunkálásból maradó nyomok meghatározott orientációval rendelkeznek. Ezen tulajdonság bizıositása különleges - szinte megoldhatatlannnak látszó követelményt állít a megmunkálást tervezõ CAM rendszer elé. A szerzõ által kidolgozott módszer lehetổvé teszi e probléma megoldását.

\section{Bevezetés}

A korszeni, gazdaságos forgácsolás ma már szinte csak váltólapkák alkalmazásával képzelhető el. A forgácsolási tulajdonságokat meghatározó tényezők:

- lapka anyaga

- lapka geometriája

- lapka bevonatolása 
Jelen előadásban a geometria - elsősorban a homlokfelület geometriájának - hatását elemzem, megvizsgálom, hogy egyes jellemző tulajdonságok hogyan befolyásolják a forgácsolásra való alkalmasságot, valamint bemutatom azt, hogy a gyártás milyen fỏ lépésekre tagozódik, $s$ ezek során melyek a legfontosabb betartandó szabályok.

\section{A homlokfelület kialakítása}

A forgácsolási feladatokat alapvetően három típusra oszthatjuk: nagyolás, elősimítás, simitás. A forgácsolási feladathoz igazodik a lapka geometriai kialakitása.

A homlokfelület geometriájának tervezésekor bonyolult feltételrendszert kell figyelembe venni [1]:

Az éltartam szempontjából az a kedvezö, ha a csúcssugár értéke maximális. A felső határt az alkatrészen elöforduló legkisebb belső rádiusz határozza meg. Mivel a nagyolás során ez nem olyan fontos szempont - a darabon úgyis marad ráhagyás -. ezért a nagyolólapka csúcssugara nagyobb lehet $(0.8$.. $2.4 \mathrm{~mm})$, míg a simítólapka csúcssugara kisebb $(0.2$.. $0.8 \mathrm{~mm})$.

A nagyoló lapka nagyon vastag forgácsolt távolít el, ugyanakkor a felületi érdességgel szemben csekélyek a követelmények. Az él terhelhetőségének javitása érdekében kis homlokszöget és/vagy élfazettát alkalmazunk. (Az élfazetta a homlokfelületnek az élnél kialakitott negativ,
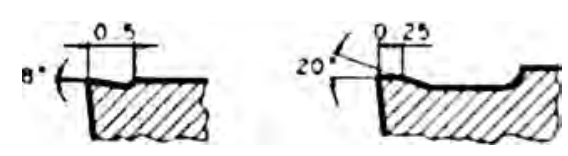

1. ábra Simitó és nagyolólapka ortogonálmetszete vagy nulla homlokszöggel rendelkező része.) Elösimitáskor is célszerü az élfazetta alkalmazása. Ügyelni kell viszont arra, hogy amennyiben a fazetta mérete nagyobb, mint a forgácsvastagság, akkor az már nem fazettaként müködik, hanem úgy, mintha az lenne a homlokfelület. Az élfazetta méretét úgy kell tehát megválasztani, hogy az kisebb legyen, mint az elösimitáskor használt szokásos forgácsvastagság értéke. A simítás során szükséges felületi minőséget általában csak élfazetta alkalmazása nélkül érhetjük el. A homlokszög növelése csökkenti a forgácsolóerőt és javítja a forgácsolt felület felületi érdességét.

Fontos feladat a forgács törése. A primer forgácstörés során a homlokfelületen elhelyezett forgácstörő elem, vagy a homlokfelület éltől távolabbi részének megfelelö kialakitása folytán a forgács görbületi sugara csőkken, ennek hatására pedig növekszik a forgácsban kialakuló feszültség. Ha ez elér egy kritikus értéket, akkor a forgács magától eltörik. Belátható, hogy vastagabb forgács esetén nagyobb görbületi sugár is elegendő a jelenség bekővetkezéséhez, vagyis nagyoló lapka esetén a forgácsszabályozó rész nem olyan meredek, mint simítólapkánál (1. ábra). Gondosan kell meghatározni azt is, hogy ez a forgácstörő rész mennyire nyúljon be a csúcs közelébe. Nagyoláskor a forgács általában széles, a forgácstörő elem egészen távol kerülhet a csúcstól. Simításkor viszont a forgácsszélesség csekély, a forgácstőrő rész csak akkor mükődik hatásosan, ha a csúcshoz egészen kőzel helyezkedik el.

A leváló forgács a homlokfelületen súrlódik. Ez káros, mert ezáltal koptatja a homlokfelületet, a súrlódás melegíti a lapkát, valamint kellően nagy nyomás esetén a forgács akár fel is tapadhat a homlokfelületre. Mérsékelhetjük ezeknek a káros jelenségeknek a hatásait, ha csökkentjük a forgács és a homlokfelület érintkezési felületének nagyságát. Ez dudor, kiemelkedés elhelyezésével, vagy a homlokfelület hullámossá tételével oldható meg. 


\section{A váltólapka gyártása}

A gyártás porkohászati úton tơrténik. Az ossszetételnek megfelelö port (WC, TiC, TaC, Co) keverik, majd a kívánt alakra sajtolják. Előzsugoritás után lehetőség van még a krétakeménységü darabok megmunkálására (erre viszont váltólapkáknál általában nincs szükség), majd a zsugoritáskor nyeri el a darab a végsõ méretét.

A kialakuló homlokfelület-alakot a sajtolószerszám geometriája határozza meg. A sajtolószerszám is keményfémből van, a megfelelő alakzat kialakitása tehát nem is olyan egyszerü. Az általánosan használt megmunkálási mód a szikrácsolás. Tehát tulajdonképpen egy lapka alakú szikraforgácsoló bélyegre van szükség, amivel elkészuil a sajtolószerszámban a homlokfelület negatívja. Ennek akkorának kell lennie, hogy a zsugoritás után kapott lapka éppen a megfelelő méretü legyen (a zsugorodás mértéke általában 18-20\%). A sajtolószerszámot a szikrácsolós után gyémántpasztával polírozzák, hogy a felülete minél fényesebb, simább legyen. Erre azért van szuikség, mert ellenkező esetben a por - főleg azokon a részeken, ahol a felületi normális a sajtolási iránytól jelentősen eltér - feltapadhat a bélyeg felületére a szerszám nyitásakor. Legkényesebb ilyen szempontból az él kơrnyéke, hiszen ennek épsége a legfontosabb kívánalom, ugyanakkor bármilyen rendellenesség (pl. sorja a szikrácsoló elektródán), ami annak környezetében található, feltapadást okozhat.

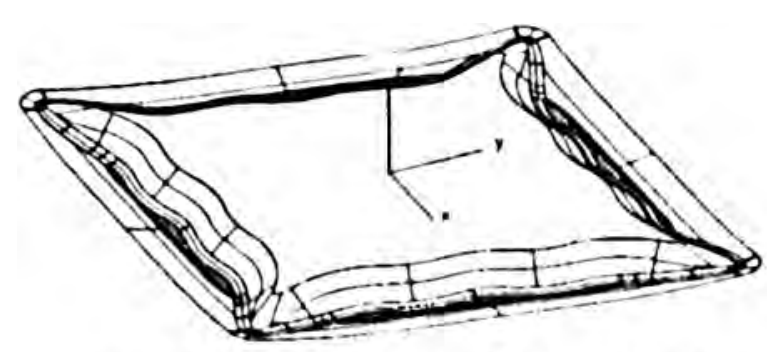

2. ábra A homlokfelület CAD modellje

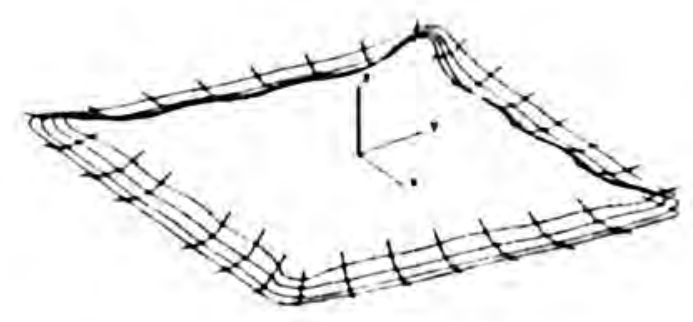

4. ábra A loft típusú felület

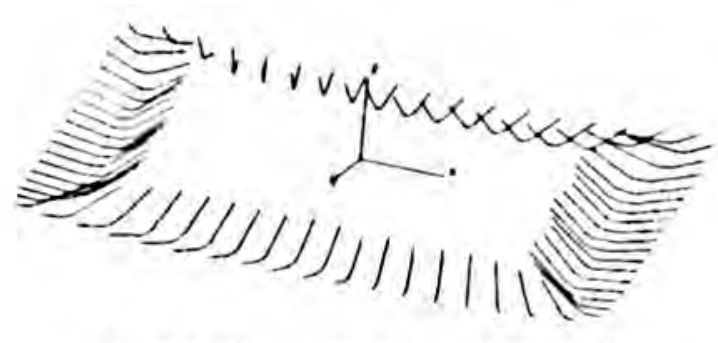

3. ábra Metszetek a kontúr mentén

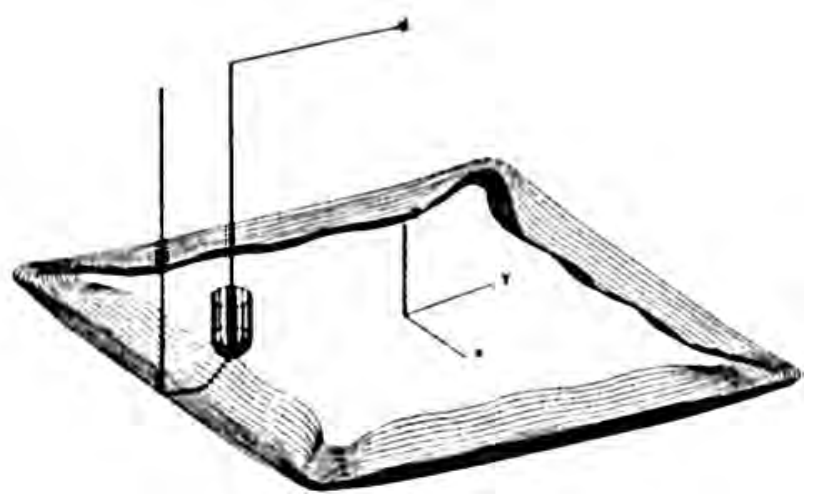

5. ábra A spirális alakú szerszámpályák

A tapasztalat szerint csak akkor kapunk megfelelő szerszámot, ha az elektróda marása során a marószerszám éle mindig a kontúrnak megfelelő görbe mentén halad, ekkor ugyanis nincs se kilépés, se 
belépés. Ha a lapka keresztmetszete mindenhol ugyanaz, akkor ennek a feltételnek a tartása nem is olyan nehéz, hiszen csupán a szerszám helyzetét kell meghatározni úgy, hogy érintse ezt a metszetet, a mozgás pedig az élnél egyenes, a csúcsnál pedig kör mentén történik. Ilyen NC programot akár házilag írt célsoftware-rel is lehet késziteni, CAD modell elkészitése nélkül. Ha azonban pl. a forgács feltapadását megakadályozó hullámokat is szeretnénk a homlokfelületen, akkor ez a módszer már nem alkalmazható. Ilyenkor el kell készíteni a homloklap CAD modelljét - bonyolultsága miatt ez általában csak felületmodellezéssel történhet -, majd ezt a modellt (2. ábra) kell a megfelelö szerszámmal és stratégiával megmunkálni. Mint a fentiekben láttuk, a "megfelelő stratégia" tulajdonképpen azt jelenti, hogy a szerszámpálya felülnézetben úgy néz ki, mint egy - a külső és a belső kontúr közötti - spirális (5. ábra). Minél több "menete" van ennek a spirálisnak, annál közelebb vannak egymáshoz a szerszámpályák, annál finomabb lesz a kapott felület.

A probléma az, hogy a CAM rendszerek nem teszik lehetövé, hogy egy bonyolult, tơbb felületböl álló modellt a fenti kívánalmaknak megfelelően munkáljunk meg. Egyetlen felületnél ez lehetséges lenne, s végülis ez adta az ötletet a megoldáshoz: a bonyolult, sok felületből álló modellt át kell alakitani egyetlen felületté. Az általam használt CAD/CAM rendszer segítségével a modellröl olyan metszetek sorozatát készítettem el, melyeknél a metszösikot a külső és belső kontúr megfelelö pontjai határozzák meg (3. ábra). Nagyon sok (6-800 db) ilyen metszet már megfelelö pontossággal jellemzi a felületet. A metszetekre azután egy loft típusú spline felületet illesztve elöáll a homlokfelületet reprezentáló egyetlen felület (4. ábra), amely már alkalmas a kívánt tulajdonságú szerszámpályák generálására (5. ábra).

\section{Összefoglalás}

Három - az ismertetett elvek alapján tervezett - lapkageometria sajtolószerszámaihoz a szerzö által kidolgozott elv alapján elkészült az NC program, a lapkák gyártása jelenleg a Magyarországon váltólapkák gyártásával foglalkozó egyetlen vállalatnál, a PORKORIT Kft-nél folyamatban van. Jelenleg is folyik a munka a pozitív lapkák sajtolása során felmerülö problémák kiküszöbölésére.

\section{Felhasznált irodalom:}

[1] I. S. Jawahir and C. A. van Luttervelt Recent Developments in Chip Conrtol Research and Applications CIRP Vol. 42/2/1993 659-693 old.

\section{Sxerző adatai:}

\section{Turi Péter PhD hallgató}

Budapesti Müszaki Egyetem

Gépgyártástechnológia Tanszék,

1521 Budapest Pf. 91.

Tel.: +36 l 4632515 Fax: +3614633178 